\title{
Argon plasma versus electrofulguration in the treatment of anal and perianal condylomata acuminata in patients with acquired immunodeficiency virus ${ }^{1}$
}

\author{
Eduardo Angelo Braga', Gaspar de Jesus Lopes Filho", Sarhan Sydney Saad"II
}

\begin{abstract}
'MSc, Fellow PhD Degree, Postgraduate Program in Interdisciplinary Surgical Science, Division of Surgical Gastroenterology, Department of Surgery, Medical School, Universidade Federal de São Paulo (UNIFESP), Sao Paulo-SP, Brazil. Conception and design of the study, acquisition of data, manuscript writing.

"PhD, Chairman Professor, Division of Surgical Gastroenterology, Department of Surgery, Medical School, UNIFESP, Sao Paulo$\mathrm{SP}$, Brazil. Critical revision, final approval.

I'PhD, Assistant Professor, Division of Surgical Gastroenterology, Department of Surgery, Medical School, UNIFESP, Sao PauloSP, Brazil. Critical revision, final approval.
\end{abstract}

\section{Abstract}

Purpose: To compare the effectiveness of anal and perianal condylomata treatment using argon plasma and electrofulguration.

Methods: From January 2013 to April 2014, 37 patients with anal and perianal condylomata, who had been diagnosed through proctological examination, oncotic cytology, polymerase chain reaction (PCR) and histology, underwent treatment with argon plasma and electrofulguration. The perianal and anal regions were divided into two semicircles. Each semicircle was treated using one of the methods by means of simple randomization. Therapeutic sessions were repeated until all clinical signs of infection by HPV were eliminated. The patients were evaluated according to several variables like the genotype of HPV, HIV infection, oncological potential per genotype, oncotic cytology and histology.

Results: Among all the variables studied, only immunosuppression due to HIV influenced the results, specifically when the fulguration method was used. There was no significant difference in effectiveness between argon and fulguration based on lesion relapse ( $p>0.05)$. However, among HIV-positive patients, fulguration presented worse results, with a significant difference $(p=0.01)$.

Conclusion: Regarding treatment of anal and perianal condylomata acuminata, comparison between applying fulguration and argon demonstrated that these methods were equivalent, but use of fulguration presented more relapses among HIV-positive patients.

Key words: Condylomata Acuminata. Argon Plasma Coagulation. Electrosurgery. Papillomaviridae. HIV Seropositivity. 


\section{- Introduction}

Human papillomavirus (HPV) infection is the sexually transmitted disease most frequently diagnosed in both men and women. The incidence of this disease has been increasing over recent years almost everywhere in the world ${ }^{1-4}$. An estimated 10 to $20 \%$ of the adult sexually active population is infected by HPV, although only $1 \%$ presents classic condyloma and $2 \%$ present the subclinical disease, which could be diagnosed by means of high-resolution anoscopy ${ }^{4-8}$. Young adults are the group with the largest number of cases of infection, reaching rates of $46 \%$ among people aged between 20 and 30 years ${ }^{1-4,7,9}$.

Coinfection between the papillomavirus and human immunodeficiency virus (HPV-HIV) can reach more than $60 \%$ of individuals infected by HIV. This is a concerning situation, given the increasing number of cases of anal squamous cell carcinoma (SCC) among these diseased individuals. Tracking programs among this population have led to a concomitant increase in the number of cases diagnosed with condylomata acuminata ${ }^{1-4,9-10}$.

Anal carcinoma used to be considered infrequent, but its frequency is growing, especially due to an increase in $\mathrm{SCC}^{11}$. At the same time, increased numbers of cases of anogenital infections due to the human papillomavirus, which causes condylomata acuminata, have been observed ${ }^{3,4,12}$. Early diagnosis, and correct treatment of the initial lesions are paramount for successful treatment of patients with condylomata acuminata as for anal carcinoma that may arise from such lesions. Diagnosing anal SCC at an early stage is often only possible due to the signs and symptoms caused by the condyloma. It is considered to be a warning sign and brings the opportunity to better investigate this at-risk population ${ }^{7,13-15}$.

Conventional electrofulguration is considered to be one of the methods with lowest relapse rates among the surgical methods available for treating condylomata acuminata ${ }^{12,16-20}$. Proper application causes only a superficial burn, but if the burn is deep and reaches the dermis or below this and the area treated is large, there is a risk of developing anal stenosis ${ }^{20-22}$.

Another factor that limits use of electrofulguration is the absence of any fine control regarding the depth of the burn and the infecting smoke produced. Care must be taken, particularly to avoid carbonization of tissue and formation of third-degree burns. These could develop as perineal infection, anal stenosis and even as gangrene ${ }^{4}$. Less than half of the patients treated have a complete response after a single session of electrofulguration ${ }^{16,20,22-26}$. Frequent follow-up is needed, to treat recurring lesions as soon as they are diagnosed ${ }^{20,23}$.

Despite the various forms of treatment for condylomata, relapses are frequent and the results are unsatisfactory ${ }^{7,14-17,20,27}$. Use of argon plasma has arisen as an alternative to use of conventional electrofulguration given the promising results presented, although more studies are needed ${ }^{15,20,24,28}$. The present study had the aim of investigating this type of treatment for application among HIV-positive patients ${ }^{12,24-26,28}$.

\section{- Methods}

The present study consisted of a prospective investigation carried out among patients with anal condyloma or perianal condyloma, or both of these. The project for this study and the free and informed consent statement for use in this study were approved by the Research Ethics Committee, Universidade Federal de Minas Gerais (COEP-UFMG) 89.531/2012, CAAE 06030112.5.0000.5149, and also by the Research Ethics Committee, Universidade Federal University de São Paulo (UNIFESP), under report number 1.156.495/2015 and CAAE 46010115.3.0000.5505. This study was registered under universal trial number (UTN) U1111-1175-1767 and on the REBEC platform under number RBR-8YTCR4.

Patients over the age of 18 years, 
with lesions caused by HPV over the whole circumference of the anal or perianal region, or both, were included in the present study. Patients who presented either unilateral condylomatous lesions or lesions that were too large for treatment at an outpatient service were not included. Patients who did not agree to participate in the study were also excluded.

From January 2013 to April 2014, a total of 93 patients were seen by the researchers at the coloproctology service for sexually transmitted diseases at the public center for specialized consultations of the municipality of Contagem, Minas Gerais. Out of this total, 46 were eligible. However, only 37 participated in the entire study. The patients were studied prospectively for 24 weeks.

The patients underwent a clinical examination, blood count, coagulogram, fasting blood glucose, HIV test, cluster of differentiation count (CD4) (for the HIV-positive patients) and the Venereal Disease Research Laboratory test (VDRL) (Tables 1 and 2). Of these patients, 20 (54.1\%) were smokers, 17 (45.9\%) were non-smokers, 10 (27\%) had undergone some method of treatment previously and 27 (73\%) had never been treated.

Table 1 - Characterization of the laboratory variables $(n=37)$.

\begin{tabular}{lc} 
Variables & $n(\%)$ \\
\hline HIV & $14(37.8)$ \\
Positive & $23(62.2)$ \\
Negative & \\
CD4 & $1(7.14)$ \\
$<200$ & $0(0.0)$ \\
200 to 399 & $13(92.86)$ \\
$\geq 400$ & $14(100.00)$ \\
Total & \\
\hline
\end{tabular}

The condylomatous lesions were diagnosed by means of proctological examinations. These examinations consisted of static and dynamic inspection, rectal touching, anoscopy and high-resolution anoscopy using 3\% acetic acid. All the patients underwent specimen collection for histology, oncotic cytology and polymerase chain reaction (PCR) evaluations.

The results from the cytological analyses were distributed between: negative for intraepithelial lesion (NIL), low-grade squamous intraepithelial lesion (LSIL) and high-grade squamous intraepithelial lesion (HSIL). Specific genotypes were identified, risk groups were categorized and the number of genotypes per patient was identified. The histological analyses were categorized regarding the lesions caused by HPV and unspecific lesions. Patients with positive VDRL were also identified ${ }^{6,8}$ (Table 2).

Table 2 - Characterization of the variables from the complementary examinations $(n=$ 37).

$\begin{array}{lc}\text { Variables } & n(\%) \\ \text { VDRL } & \\ \text { Positive } & 4(10.8) \\ \text { Negative } & 33(89.2) \\ \text { PCR } & \\ \text { Positive } & 36(97.3) \\ \text { Negative } & 1(2.7) \\ \text { Genotype } & \\ \text { HPV11 } & 7(14.0) \\ \text { HPV16 } & 5(10.0) \\ \text { HPV6 } & 18(36.0) \\ \text { HPV18 } & 2(4.0) \\ \text { HPV31 } & 3(6.0) \\ \text { HPV33 } & 3(6.0) \\ \text { HPV35 } & 2(4.0) \\ \text { HPV56 } & 2(4.0) \\ \text { HPV58 } & 2(4.0) \\ \text { HPV68 } & 1(2.0) \\ \text { HPV70 } & 1(2.0) \\ \text { HPV72 } & 1(2.0) \\ \text { Undefined type } & 2(4.0) \\ \text { Negative } & 1(2.0) \\ \text { Genotypes categorized as } & \\ \text { High risk } & 21(42.0) \\ \text { Low risk } & 26(52.0) \\ \text { Others (negative or undefined type for the } & 3(6.0) \\ \text { method used) } & \\ \text { Impairment level per genotype } & \\ \text { 1 } & 28(82.4) \\ \text { 2 } & 2(5.9) \\ \text { > 2 } & 4(11.8) \\ \text { Total } & 34(100.0) \\ \text { Oncotic cytology } & \\ \text { Negative for intraepithelial lesion } & 18(48.6) \\ \text { Low-grade squamous intraepithelial lesion } & 18(48.6) \\ \text { High-grade squamous intraepithelial lesion } & 1(2.7) \\ \text { Histological result } & 32(86.5) \\ \text { Condylomata acuminata } & 5(13.5) \\ \text { Unspecific lesions } & \\ & \end{array}$


Condylomata were treated by applying argon plasma and fulguration. To compare these two treatment methods, the anal and perianal region of the same individual was divided into two semicircles, following the model proposed by Billingham ${ }^{19}$. Each treatment method was applied to one semicircle, chosen by simple randomization. Applications were performed until the lesions disappeared, from a macroscopic point of view. The treatment was performed respecting the epithelial planes, with the objectives of improving results and minimizing complications, as described by Reid ${ }^{29}$. During the postoperative period, the patients were evaluated by means of fortnightly proctological examinations during the first month and then monthly examinations until the sixth month of follow-up. If residual lesions were diagnosed, new applications were performed, respecting the type of treatment previously performed on the given semicircle ${ }^{18,28}$.

The results were analyzed statistically. Qualitative variables were described by means of the absolute frequency and percentages. Quantitative variables were assessed using the mean and standard deviation (SD). Pearson's asymptotic and exact chi-square tests were used in the association analyses. The Z-test was initially used to analyze the effectiveness of the methods by comparing proportions. The Kappa test was then used to assess the agreement between the methods. The significance level was set at 0.05. The software used was the Statistical Package for the Social Sciences
(SPSS), version 20.0, and Stata 9.1.

\section{Results}

A total of 119 operations were performed among the 37 patients. Argon plasma was applied on the right side of 22 patients and on the left side of 15 . Fulguration was applied on the right side of 15 patients and on the left side of the other 22. Relapses were observed in 16 individuals (43.2\%) who were treated with argon and in 19 individuals (51.4\%) who were treated with fulguration, with no significant difference ( $p=0.478$ ). The variables of age group, gender, age when sexual life began, anal coitus, number of partners, smoking, anal manipulation, location of condylomata, previous treatment, cytology and HPV genotype were evaluated regarding their possible influence on relapses, but none of them showed statistically significant values.

Statistical significance was only observed for the fulguration method when applied to seropositive patients, in comparison with seronegative patients (Table 3 ). The value of the Kappa agreement test regarding comparison of methods was 0.731 ( $p<0.001)$.

Since HIV was identified as a determining factor for a higher number of relapses in areas treated with fulguration, the patients were then categorized regarding the virus and CD4 lymphocyte count. Statistical significance was observed for areas of seropositive patients even when the CD4 lymphocyte count was greater than 400 (Table 4). 
Table 3 - Results from analysis on the association between relapse after fulguration or argon treatment and the variables of the study.

\begin{tabular}{|c|c|c|c|c|c|c|c|}
\hline \multirow{3}{*}{ Variable } & \multicolumn{7}{|c|}{ Relapse } \\
\hline & \multirow{2}{*}{\multicolumn{3}{|c|}{ Fulguration }} & \multicolumn{3}{|c|}{ Argon } & \multirow[b]{2}{*}{ Total } \\
\hline & & No & $p$-Value & Yes & No & p-value & \\
\hline $\begin{array}{l}\text { Age group } \\
\leq 30 \text { years } \\
>30 \text { years }\end{array}$ & $\begin{array}{l}9(52.9) \\
10(50.0)\end{array}$ & $\begin{array}{l}8(47.1) \\
10(50.0)\end{array}$ & $0.858^{1}$ & $\begin{array}{l}9(52.9) \\
7(35.0)\end{array}$ & $\begin{array}{c}8(47.1) \\
13(65.0)\end{array}$ & $0.272^{1}$ & $\begin{array}{l}17 \\
20\end{array}$ \\
\hline Gender & & & & & & & \\
\hline $\begin{array}{l}\text { Female } \\
\text { Male }\end{array}$ & $\begin{array}{c}2(66.7) \\
17(50.0)\end{array}$ & $\begin{array}{c}1(33.3) \\
17(50.0)\end{array}$ & $>0.999^{2}$ & $\begin{array}{l}3(100.0) \\
13(38.2)\end{array}$ & $\begin{array}{c}0(0.0) \\
21(61.8)\end{array}$ & $0.072^{2}$ & $\begin{array}{c}3 \\
34\end{array}$ \\
\hline $\begin{array}{l}\text { Initiated sexual life at } \\
\leq 20 \text { years } \\
>20 \text { years }\end{array}$ & $\begin{array}{l}18(51.4) \\
1(50.0)\end{array}$ & $\begin{array}{l}17(48.6) \\
1(50.0)\end{array}$ & $>0.999^{2}$ & $\begin{array}{c}15(42.9) \\
1(50.0)\end{array}$ & $\begin{array}{l}20(57.1) \\
1(50.0)\end{array}$ & $0.072^{2}$ & $\begin{array}{c}35 \\
2\end{array}$ \\
\hline $\begin{array}{l}\text { Number of partners } \\
<2 \\
2 \text { to } 5 \\
\geq 6 \\
\text { Anal coitus }\end{array}$ & $\begin{array}{l}5(31.3) \\
7(77.8) \\
7(58.3)\end{array}$ & $\begin{array}{l}11(68.8) \\
2(22.2) \\
5(41.7)\end{array}$ & $0.077^{2}$ & $\begin{array}{l}5(31.3) \\
6(66.7) \\
5(41.7)\end{array}$ & $\begin{array}{l}11(68.8) \\
3(33.3) \\
7(58.3)\end{array}$ & $0.227^{1}$ & $\begin{array}{c}16 \\
9 \\
12\end{array}$ \\
\hline $\begin{array}{l}\text { Yes } \\
\text { No } \\
\text { Anal manipulation }\end{array}$ & $\begin{array}{l}16(50.0) \\
3(60.0)\end{array}$ & $\begin{array}{l}16(50.0) \\
2(40.0)\end{array}$ & $>0.999^{2}$ & $\begin{array}{c}13(40.6) \\
3(60.0)\end{array}$ & $\begin{array}{l}19(59.4) \\
2(40.0)\end{array}$ & $0.634^{2}$ & $\begin{array}{c}32 \\
5\end{array}$ \\
\hline $\begin{array}{l}\text { Yes } \\
\text { No } \\
\text { Smoking }\end{array}$ & $\begin{array}{l}11(50.0) \\
8(53.3)\end{array}$ & $\begin{array}{l}11(50.0) \\
7(46.7)\end{array}$ & $0.842^{2}$ & $\begin{array}{l}9(40.9) \\
7(46.7)\end{array}$ & $\begin{array}{l}13(59.1) \\
8(53.3)\end{array}$ & $0.729^{1}$ & $\begin{array}{l}22 \\
15\end{array}$ \\
\hline $\begin{array}{l}\text { Yes } \\
\text { No } \\
\text { HIV }\end{array}$ & $\begin{array}{l}12(60.0) \\
7(41.2)\end{array}$ & $\begin{array}{c}8(40.0) \\
10(58.8)\end{array}$ & $0.254^{1}$ & $\begin{array}{c}10(50.0) \\
6(35.3)\end{array}$ & $\begin{array}{l}10(50.0) \\
11(64.7)\end{array}$ & $0.368^{1}$ & $\begin{array}{l}20 \\
17\end{array}$ \\
\hline $\begin{array}{l}\text { Positive } \\
\text { Negative }\end{array}$ & $\begin{array}{l}11(78.6) \\
8(34.8)\end{array}$ & $\begin{array}{c}3(21.4) \\
15(65.2)\end{array}$ & $0.010^{1}$ & $\begin{array}{l}8(57.1) \\
8(34.8)\end{array}$ & $\begin{array}{c}6(42.9) \\
15(65.2)\end{array}$ & $0.183^{1}$ & $\begin{array}{l}14 \\
23\end{array}$ \\
\hline Location of the condylomata & & & & & & & \\
\hline Anal & $3(37.5)$ & $5(62.5)$ & & $2(25.0)$ & $6(75.0)$ & & 8 \\
\hline $\begin{array}{l}\text { Perianal } \\
\text { Perianal and anal }\end{array}$ & $\begin{array}{l}2(66.7) \\
11(52.4)\end{array}$ & $\begin{array}{l}1(33.3) \\
10(47.6)\end{array}$ & $0.829^{2}$ & $\begin{array}{l}2(66.7) \\
8(38.1)\end{array}$ & $\begin{array}{l}1(33.3) \\
13(61.9)\end{array}$ & $0.232^{2}$ & $\begin{array}{c}3 \\
21\end{array}$ \\
\hline $\begin{array}{l}\text { Other } \\
\text { Previous treatment }\end{array}$ & $3(60.0)$ & $2(40.0)$ & & $4(80.0)$ & $1(20.0)$ & & $\begin{array}{l}21 \\
5\end{array}$ \\
\hline $\begin{array}{l}\text { Previous treatment } \\
\text { Yes } \\
\text { No }\end{array}$ & $\begin{array}{c}7(70.0) \\
12(44.4)\end{array}$ & $\begin{array}{c}3(30.0) \\
15(55.6)\end{array}$ & $0.269^{2}$ & $\begin{array}{c}6(60.0) \\
10(37.0)\end{array}$ & $\begin{array}{l}4(40.0) \\
17(63.0)\end{array}$ & $0.274^{2}$ & $\begin{array}{l}10 \\
27\end{array}$ \\
\hline $\begin{array}{l}\text { Oncotic cytology } \\
\text { NIL } \\
\text { LSIL } \\
\text { HSIL } \\
\text { Genotype categorized as }\end{array}$ & $\begin{array}{l}8(44.4) \\
10(55.6) \\
1(100.0)\end{array}$ & $\begin{array}{c}10(55.6) \\
8(44.4) \\
0(0.0)\end{array}$ & $0.625^{2}$ & $\begin{array}{c}7(38.9) \\
8(44.4) \\
1(100.0)\end{array}$ & $\begin{array}{c}11(61.1) \\
10(55.6) \\
0(0.0)\end{array}$ & $0.611^{2}$ & $\begin{array}{l}18 \\
18 \\
1\end{array}$ \\
\hline $\begin{array}{l}\text { High risk } \\
\text { Low risk }\end{array}$ & $\begin{array}{l}7(70.0) \\
12(50.0)\end{array}$ & $\begin{array}{c}3(30.0) \\
12(50.0)\end{array}$ & 27127 & $\begin{array}{c}6(60.0) \\
10(41.7)\end{array}$ & $\begin{array}{c}4(40.0) \\
14(58.3)\end{array}$ & $0223^{2}$ & $\begin{array}{l}10 \\
24\end{array}$ \\
\hline $\begin{array}{l}\text { Others (negative or undefined } \\
\text { type) }\end{array}$ & $0(0.0)$ & $3(100.0)$ & & $0(0.0)$ & $3(100.0)$ & & 3 \\
\hline
\end{tabular}

${ }^{1}$ Asymptotic Pearson's chi-square test

${ }^{2}$ Exact Pearson's chi-square test

Table 4 - Results from analysis on the association between effectiveness variables and CD4.

\begin{tabular}{|c|c|c|c|c|c|}
\hline \multirow[b]{2}{*}{ Variables } & \multirow{2}{*}{$\begin{array}{c}\text { HIV } \\
\text { negative }\end{array}$} & \multicolumn{2}{|c|}{ HIV positive } & \multirow[b]{2}{*}{ Total } & \multirow[b]{2}{*}{$p$-Value } \\
\hline & & $\mathrm{CD} 4 \leq 400$ & CD4 $>400$ & & \\
\hline \multicolumn{6}{|c|}{ Argon relapse } \\
\hline Yes & $8(34.8)$ & $8(34.8)$ & $7(58.3)$ & $9(75.0)$ & \multirow{2}{*}{0.4732} \\
\hline No & $15(65.2)$ & $15(65.2)$ & $5(41.7)$ & $3(25.0)$ & \\
\hline \multicolumn{6}{|c|}{ Fulguration relapse } \\
\hline $\begin{array}{l}\text { Yes } \\
\text { No }\end{array}$ & $\begin{array}{l}1(50.0) \\
1(50.0)\end{array}$ & $\begin{array}{c}2(100.0) \\
0(0.0)\end{array}$ & $\begin{array}{l}16 \\
21\end{array}$ & $\begin{array}{l}19 \\
18\end{array}$ & 0.0222 \\
\hline
\end{tabular}

2Exact Pearson's chi-square test. 


\section{- Discussion}

Operations using ionized argon gas (argon plasma), which is inert and non-toxic, are based on its physicochemical properties. This method allows transference of electrical energy generated by an electrosurgical unit to the target tissue ${ }^{24,28}$. The ionized gas transfers energy without contact between the electrode and the tissue surface, which enables energy distribution according to the impedance of the tissue. This distribution occurs in a predictable manner. As tissue composition changes, tissue conductivity also changes, thus avoiding points at which tissue lesions deepen with formation of eschar ${ }^{24,25,28}$. The ion flow generated and conducted by argon follows the path of least electrical resistance, regardless of the position of the electrode in relation to the tissue, and also regardless of the direction of the flow of the gas $^{24,25,28}$. This phenomenon is advantageous when the treatment is performed in the anal canal, because it improves access to the squamouscolumnar transition ${ }^{28}$.

The depth of the burn caused by the method is predictable. It can reach only between 2 and $4 \mathrm{~mm}$ in thickness in either skin or mucosa, according to the flow and power used, which stops formation of deep lesions that would increase the chance of postoperative infection and pain ${ }^{24,25,28}$. The depth reached by argon plasma is more than sufficient to eradicate lesions caused by HPV, considering that by reaching depths of $2 \mathrm{~mm}$, more than $90 \%$ of lesions are eradicated. In the perianal regions, the recommendation is to reach $1 \mathrm{~mm}$ in depth for skin with no hair and up to $2 \mathrm{~mm}$ in skin with hair ${ }^{20,24,25}$. Involvement of cutaneous appendices demands greater attention regarding the depth at which argon plasma is applied. Following this criterion, residual lesions are due more to the existence of compromised lateral margins than to insufficient depth of treatment ${ }^{28,29}$.

The sensitivity of the PCR method in this sample was almost $98 \%$, while other studies in the literature found values close to $75 \%^{5,30}$.

Genotypes 6 and 11 were the most common. A substantial number of patients with high-risk genotypes for anal carcinoma were also observed. Moreover, half of the patients presented lesions compatible with LSIL in their cytological evaluations. Regarding division of the genotypes into three categories, the high-risk and low-risk genotypes presented similar occurrence ${ }^{1,4,6,20}$. HPV genotyping, which today is more associated with scientific research than with clinical practice, can individualize patients who might be more susceptible to evolving to carcinoma, due to presence of a high-risk genotype such as types 16 or $18^{1,2,4,27}$.

All the patients underwent biopsies. Lesions caused by HPV were confirmed in 32 individuals $(86.5 \%)$, while the histology of the remaining five was unspecific. Oncotic cytological evaluations were performed on all the patients, with sensitivity of $51.3 \%$ for detection of cytological lesions caused by HPV, which is in accordance with the literature ${ }^{7,8}$. Through combining evaluations using PCR, histology and cytology, diagnoses of HPV were made in the cases of $100 \%$ of the patients. This demonstrated that the methods complemented each other and can be included in systematization of treatments for patients with anal and perianal HPV infections, as proposed by Nadal et al.30 (Table 2).

The effectiveness of the methods for treating condylomata was measured through the number of sessions needed to eradicate the clinical lesions caused by HPV. The areas treated with fulguration underwent up to three therapeutic sessions, while areas treated with argon required up to four sessions. Although there was no statistical difference in the number of therapeutic sessions, the lower number of applications in the fulguration group may have been due to the aggressiveness of the method. Regarding the argon method, 
more areas responded to a single therapeutic session (21 vs. 18), demonstrating, at least in theory, the greatest potential for eliminating subclinical reservoirs around the clinical lesion, although with no statistical difference. Eradication of condylomatous lesions among all the patients was reached after 120 days of treatment, which confirms data from the literature showing that different types of treatment need more than one session to eradicate clinical lesions ${ }^{20}$.

None of the variables studied, with the exception of HIV, was able to influence the response to treatment of either method. The epidemiology and pathogenesis of condylomata caused by different viral genotypes, particularly the most aggressive types, may indicate which patients should be referred for differentiated follow-up because they have greater chances of evolving to carcinoma of anal and perianal squamous cells $s^{2,11,12,20}$. Genotypes that were more aggressive from an oncogenic point of view were expected to lead to a greater number of relapses, but there was no difference between treatments ${ }^{1,13}$. The HPV genotype did not influence the number of relapses (Table 3).

The relapse rate was higher among HIV-positive patients when the condylomata was treated using electrofulguration. This was observed through the greater number of sessions needed, in comparison with seronegative even when the CD4 lymphocyte count was greater than 400 (Table 4). This was not seen with use of argon. In this case, the areas treated among HIV-negative and HIVpositive patients did not present any statistical difference regarding the number of relapses (Table 3).

\section{- Conclusions}

The application of argon plasma or fulguration to treat anal and perianal condylomata showed similar effectiveness. However, application of argon plasma was not influenced by serological factors, compared with fulguration, which was statistically less effective in treating HIV-positive patients.

\section{References}

1. Bosch FX, Broker TR, Forman D, Moscicki $A B$, Gillison ML, Doorbar J, Stern PL, Stanley M, Arbyn M, Poljak M, Cuzick J, Castle PE, Schiller JT, Markowitz LE, Fisher WA, Canfell K, Denny LA, Franco EL, Steben M, Kane MA, Schiffman M, Meijer CJ, Sankaranarayanan R, Castellsagué $\mathrm{X}$, Kim JJ, Brotons $\mathrm{M}$, Alemany $\mathrm{L}$, Albero G, DiazM, deSanjoséS. Comprehensive control of human papillomavirus infections and related diseases. Vaccine. 2013;31(Suppl 7):H1-31. PMID: 24332295.

2. Uronis HE, Bendell JC. Anal cancer: an overview. Oncologist. 2007;12(5):524-34. PMID: 17522240.

3. Linhares AC, Villa LL. Vaccines against rotavirus and human papillomavirus (HPV). J Pediatr. 2000;82:S25-4. PMID: 16786101.

4. Tamalet C, Ravaux I, Dhiver C, Menard A, Colson P, Stein A. Feasibility and acceptability of anal self-sampling for human papillomavirus screening in HIV-infected patients. Intervirology. 2016;59:118-22. PMID: 27923228.

5. Mathews WC. Screening for anal dysplasia associated with human papillomavirus. Top HIV Med. 2003;11(2):45-9. PMID: 12717041.

6. Lindsey K, DeCristofaro C, James J. Anal Pap smears: Should we be doing them? J Am Acad Nurse Pract. 2009;21(8):437-43. PMID: 19689440.

7. Roberts JR, Siekas LL, Kaz AM. Anal intraepithelial neoplasia: a review of diagnosis and management. World J Gastrointest Oncol. 2017;9(2):50-61. PMID: 28255426.

8. Longacre TA, Kong CS, Welton ML. Diagnostic problems in anal pathology. Adv Anat Pathol. 2008;15(5):263-78. PMID: 18724100.

9. Palefsky JM, Holly EA, Ralston ML, Da Costa $M$, Greenblatt R. Prevalence and risk factors for anal human papillomavirus infection in human immunodeficiency virus (HIV)positive and high-risk HIV-negative women. J Infect Dis. 2001;183:383-91. PMID: 
11133369.

10.Mathews WC, Agmas W, Cachay ER, Cosman BC, Jackson C. Natural history of anal dysplasia in an HIV-infected clinical care cohort: estimates using multi-state markov modeling. PLoS One. 2014;9(8):e104116. PMID: 25101757.

11.Palefsky JM. Biology of HPV in HIV infection. Adv Dent Res. 2006;19(1):99-105. PMID: 16672559.

12.Martins CR. HPV-induced anal dysplasia: what do we know and what can we do about it? Hopkins HIV Rep. 2001;13(3):3-5. PMID: 12085825.

13.Welton ML, Sharkey FE, Kahlenberg MS. The etiology and epidemiology of anal cancer. Surg Oncol Clin N Am. 2004;13(2):263-75. PMID: 15137956.

14.Scheinfeld N. Update on the treatment of genital warts. Dermatol Online J. 2013;19(6):18559. PMID: 24011309.

15.Viazis N, Vlachogiannakos J, Vasiliadis K, Theodoropoulos I, Saveriadis A, Karamanolis DG. Earlier eradication of intra-anal warts with argon plasma coagulator combined with imiquimod cream compared with argon plasma coagulator alone: a prospective, randomized trial. Dis Colon Rectum. 2007;50(12):2173-9. PMID: 17914655.

16.Wiley DJ, Douglas J, Beutner K, Cox T, Fife K, Moscicki $A B$, Fukumoto L. External genital warts: diagnosis, treatment, and prevention. Clin Infect Dis. 2002;35(2):S210-24. PMID: 12353208.

17.Lopaschuk C. New approach to managing genital warts. Can Fam Physician. 2013;59:731-6. PMID: 23851535.

18.Leszczyszyn J, Lebski I, Lysenko L, Hirnle L, Gerber H. Anal Warts (Condylomata Acuminata) - Current Issues and Treatment Modalities. Adv ClinExp Med. 2014;23(2):30711. PMID: 24913124.

19.Billingham RP, Lewis FG. Laserversus electrical cautery in the treatment of condylomata acuminata of the anus. Surg Gynecol Obstet. 1982;155(6):865-7. PMID: 6890718.

20.Thurgar E, Barton S, Karner C, Edwards S. Clinical Effectiveness and Cost-Effectiveness of Interventions for the treatment of anogenital warts: systematic review and economic evaluation. Helth Technol Assess. 2016;20(24):v-vi, 1-486. PMID: 27034016.

21.Badiu DC, Manea CA, Mandu M, Chiperi V, Marin IE, Mehedintu C, Aiordachioae G, Vasca V. Giant Perineal Condyloma Acuminatum (Buschke-Löwenstein Tumour): a case report. Chirurgia. 2016;111:435-8. PMID: 27819643. 22.D’Ambrogio A, Yerly S, Sahli R, Bouzourene $H$, Demartines N, Cotton M, Givel JC. Human papilloma virus type and recurrence rate after surgical clearance of anal condylomata acuminata. Sex Transm Dis. 2009. 36(9):53640. PMID: 19543141.

23. Handisurya A, Rieger A, Bago-Horvath Z, Schellenbacher C, Bankier A, Salat, Stingl $G$, Kirnbauer R. Rapid progression of an anal Buschke-Lowenstein tumor into a metastatising squamous cell carcinoma in an HIV-infected patient. Sex Transm Infect. 2009;85(4):261-3. PMID: 19625295.

24.Sarmento JA, Barros L, Lisboa C, David $\mathrm{L}$, Veloso T. Treatment of anal canal condylomata acuminata (CA) with Argon Plasma: first results of a new indication. Am J Gastroenterol. 2003;98(9):S120. doi: 10.1111/j.1572-0241.2003.08091.x.

25.Ferizi M, Gercari A, Pajaziti L, Blyta Y, Kocinaj A, Dobruna S. Condyloma acuminata in child and laser therapy: a case report. Cases J. 2009;2(1):123. doi: 10.1186/1757-1626-2123.

26.Oh HK, Moon SH, Ryoo S, Choe EK, Park KJ. Results of surgical treatment on benign anal disease in Korean HIV-positive patients. J Korean Med Sci. 2014;29:1260-5. PMID: 25246745.

27.Workowski KA, Bolan GA. Sexually transmitted diseases treatment guidelines. centers for disease control and prevention. MMWR Recomm Rep. 2015;64(RR-03):1137. PMID: 26042815.

28.Braga EA, Nunes TA. [Treatment of anal and perianal condylomata acuminata with argon plasma]. Gastroenterol Endosc Dig. 2011;30(4):28.

29.Reid R. The management of genital condylomas, intraepithelial neoplasia, and vulvodynia. Obstet Gynecol Clin North 
Am.1996;23(4):917-91. PMID: 8989781.

30.Manzione TS, Nadal SR, Calore EE, Manzione

CR. Local control of human papillomavirus infection after anal condylomata acuminata eradication. Rev Col Bras Cir. 2014;42(2):8791. PMID: 24918720.

\section{Correspondence:}

Eduardo Angelo Braga

Rua Bernardo Guimarães, 1020

30140-084 Belo Horizonte - MG Brasil

Tel.: (55 31)98896-0000

edubragamd@hotmail.com

Received: Feb 16, 2017

Review: Apr 14, 2017

Accepted: May 18, 2017
Conflict of interest: none

Financial source: none

${ }^{1}$ Research performed at Postgraduate Program in Interdisciplinary Surgical Science, Escola Paulista de Medicina, Universidade Federal de São Paulo (UNIFESP), Brazil. Part of PhD degree thesis. Tutor: Prof. Gaspar de Jesus Lopes Filho. 


\section{Erratum}

Manuscript: Argon plasma versus electrofulguration in the treatment of anal and perianal condylomata acuminata in patients with acquired immunodeficiency virus

Publication: Acta Cir Bras. 2017;32(6):482-491.

DOI: http://dx.doi.org/10.1590/s0102-865020170060000009

On page 486 of the original publication, instead of this Table 4:

Table 4 - Results from analysis on the association between effectiveness variables and CD4.

\begin{tabular}{|c|c|c|c|c|c|}
\hline \multirow[b]{2}{*}{ Variables } & \multirow{2}{*}{$\begin{array}{c}\text { HIV } \\
\text { negative }\end{array}$} & \multicolumn{2}{|c|}{ HIV positive } & \multirow[b]{2}{*}{ Total } & \multirow[b]{2}{*}{ p-Value } \\
\hline & & $\mathrm{CD} 4 \leq 400$ & CD4 $>400$ & & \\
\hline \multicolumn{6}{|c|}{ Argon relapse } \\
\hline Yes & $8(34.8)$ & $8(34.8)$ & 7 (58.3) & $9(75.0)$ & \multirow{2}{*}{0.4732} \\
\hline No & $15(65.2)$ & $15(65.2)$ & $5(41.7)$ & $3(25.0)$ & \\
\hline \multicolumn{6}{|c|}{ Fulguration relapse } \\
\hline $\begin{array}{l}\text { Yes } \\
\text { No }\end{array}$ & $\begin{array}{l}1(50.0) \\
1(50.0)\end{array}$ & $\begin{array}{c}2(100.0) \\
0(0.0)\end{array}$ & $\begin{array}{l}16 \\
21\end{array}$ & $\begin{array}{l}19 \\
18\end{array}$ & 0.0222 \\
\hline
\end{tabular}

${ }^{2}$ Exact Pearson's chi-square test.

Consider this Table 4:

Table 4 - Results from analysis on the association between effectiveness variables and CD4.

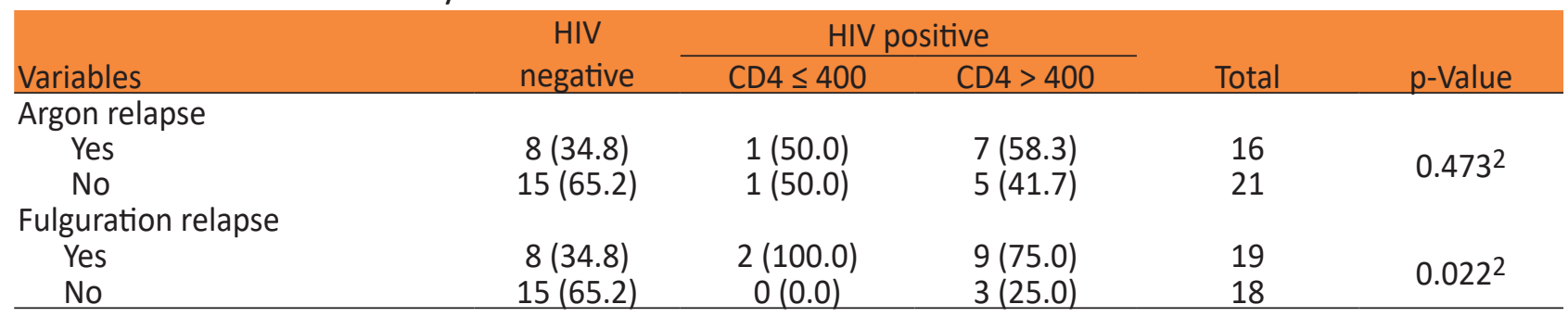

${ }^{2}$ Exact Pearson's chi-square test. 